\title{
Information Economics and Design of Organizations
}

The efforts of our current Guest Editor, professor Donald M. Lamberton of Melbourne, Australia, are certainly going to be appreciated by the HSM readership. This Special issue of HSM has been proposed, designed and organized by prof. Lamberton.

Information (or Knowledge) Economics has certainly been nurtured on the pages of Human Systems Management: the topic is timely and the information/knowledge impacts on organization design equally so.

Yet, classical economics does not know how to treat, measure and formalize information/knowledge and its dizzying mathematical superstructures do not even try to capture this most important form of capital. Without knowledge nothing can ever work, yet knowledge is treated as either given or intangible in mainstream economics. That is sad.

This sadness of lost opportunities permeates also the thinking of one of the classical old-timers, prof. Kenneth J. Arrow, who received a Nobel Prize in 1972 largely for his mathematical expressions of equilibrium theory, a theory already quite 'dead' in the 90 s.

When asked [1] what areas of economics he would explore if starting his career now, Arrow points to big theoretical questions. 'I think I'd be concerned, about the role of knowledge in economics', he says, that is, what people know and how they acquire knowledge.

"What do you mean by "knowing a thing"? I realize that sounds very theoretical', Arrow says, somewhat apologetically. But most economic theories are based on the idea that consumers know

IOS Press

Human Systems Management 11 (1992) 49-50
- or don't know - something. And what economists don't know, he adds, is 'to what extent knowledge matters for economic behavior'.

So, according to Arrow, what economists don't know is the role of major and dominant, allencompassing form of capital: human knowledge. Is economics, through its own retired giants, only now discovering the role of epistemology? How and why could it happen? Does Arrow know?

In the meantime, the Japanese are safely stating and practicing basic precepts of knowledge economy [2]: 'In an economy where the only certainty is uncertainty, the one sure source of lasting competitive advantage is knowledge'. Ikujiro Nonaka of Hitotsubashi University in Tokyo insists that, despite all the talk about 'brainpower' and 'intellectual capital', few managers grasp the true nature of the knowledge-creating company - let alone know how to manage it. The reason: they misunderstand what knowledge is and what companies must do to exploit it.

Deeply ingrained in the tradition of Western management, from Frederick Taylor to Herbert Simon (another Nobel laureate), is a view of the organization as a machine for 'information processing'. According to this view, the only useful knowledge is formal and systematic - hard (read: quantifiable) data, codified procedures, universal principles. And the key metrics for measuring the value of new knowledge are similarly hard and quantifiable - increased efficiency, lower costs, improved return on investment [2].

This is more than unfortunate. Knowledge is not symbols, descriptions, records, data and information. Knowledge is action or 'in-formation', more precisely, purposeful coordination of action. There is nothing intangible about knowing how to 
milk a cow: return from the stable with a pail of fresh milk. There is nothing more pathetic that 'talking' about milking cows with no milk in sight. Where is the beef? nobody asks anymore.

Simonian symbols, documents and records are the organizational enemy. They are expensive, create bureaucracies and administrative fiefdoms, take up storage space, and add staff [3]. Modern firms are recognizing the opportunity to bring the work to the people instead of the people to the work, and to locate operations on the basis of labor force cost and quality and ease of coordination.

Peter G.W. Keen [3] challenges the field of information technology: 'It is shifting from a tradition of computing, where telecommunications was an add-on, to one of integrated technology platforms, where telecommunications provides the highway system into which computing applications fit'. Business managers are moving from a tradition where they could avoid, delegate, or ignore decisions about information technologies to one where they cannot create a marketing, product, inter- national, organizational, or financial plan that does not involve such decisions.

Professor Lamberton and his colleagues have now issued a similar challenge to the researchers, economists and managers, around Human Systems Management: no theory and no practice, in both economics and management, can and will afford to ignore the dominant role of information and knowledge in any of its observations, descriptions, explanations and recommendations.

Milan Zeleny

\section{References}

[1] 'Coping with Math Anxiety', Scientific American, January 1992: 142.

[2] Keen, P.G.W., Shaping the Future: Business Design through Information Technology (Harvard Business School Press, Cambridge, MA) 1991.

[3] Nonaka, I., 'The Knowledge-Creating Company', Harvard Business Review, November-December 1991: 96-104. 